Research Article

\title{
Declining COVID-I9 Mortality with the Lockdown in India
}

\author{
Ankur Gupta', Geeta Singh ${ }^{2}$ \\ ${ }^{1}$ Consultant, Gorakhpur Environmental Action Group. \\ ${ }^{1}$ MTech Scholar-Centre of Excellence in Disaster Mitigation and Management, Indian Institute of Technology Roorkee (IIT- \\ Roorkee), Uttarakhand, India. \\ ${ }^{2}$ Assistant Professor, Department of Chemistry, DDU Gorakhpur University, Gorakhpur, Uttar Pradesh, India. \\ DOI: https://doi.org/10.24321/0019.5138.202129
}

\section{I $\quad \mathbf{N} \quad \mathbf{F} \quad \mathbf{O}$}

\section{Corresponding Author:}

Geeta Singh, Deen Dayal Upadhyaya Gorakhpur

University, Gorakhpur, Uttar Pradesh, India.

E-mail Id:

geetasanger@gmail.com

Orcid Id:

https://orcid.org/0000-0001-9323-5842

How to cite this article:

Gupta A, Singh G. Declining COVID-19 Mortality with the Lockdown in India. J Commun Dis. 2021; 53(2): 76-81.

Date of Submission: 2021-04-14

Date of Acceptance: 2021-06-14

\section{$\begin{array}{llllllll}\mathbf{A} & \mathbf{B} & \mathbf{S} & \mathbf{T} & \mathbf{R} & \mathbf{A} & \mathbf{C} & \mathbf{T}\end{array}$}

Background \& Objectives: Nationwide lockdown was imposed in India to contain the spread of COVID-19, -which had its own associated benefits. Though lockdown caused substantial losses to the various sectors of people, but it served the very purpose for which it was imposed in the nation in an indirect way and the same has been discussed in this article. This article has been developed with a view of reflecting the impact of disease and declining COVID mortality further to the imposition of lockdown in India.

Methods: An exploratory research technique was used for studying the impact of lockdown on mortality rate due to COVID-19 by conducting data analysis on openly available situation reports of the WHO. Further, the adverse impacts of COVID-19 on migrants, women, and children have been discussed in this article.

Results: Though the positive cases of COVID-19 are rising with the removal of the lockdown but the mortality rate is continuously reducing post the completion of lockdown. Also, the article reveals that the most adversely affected due to the disease in India are migrants, women, and children.

Interpretations and Conclusions: India, having a population of more than 200 million, has got the lowest COVID mortality rate among the countries with a population of more than 200 million. The COVID-19 mortality rate in India started declining further to the imposition of lockdown. All sections of the society got substantially impacted by the pandemic but the ones majorly impacted are women, children and migrant workers. The economical shortfall due to imposed lockdown and pandemic is recovering at a gradually increasing rate but still the COVID precautionary measures need to be adopted by all, till the government asks for not following the same.

Keywords: COVID Immunity, COVID-19, Migrants, COVID Mortality, India, Lockdown 


\section{Introduction}

Coronaviruses, a subfamily of the Coronaviridae family, are positive-strand RNA viruses with the largest genome of all known RNA viruses. Coronavirus is a group of related viruses which adversely affect the health of mammals and birds..$^{1,2}$ The history of human coronavirus began in 1965 with the study of 2 researchers, who identified that coronaviruses are quite commonly found in the respiratory tract leading to upper respiratory tract infections. ${ }^{3} \mathrm{~A}$ few of the commonly known coronaviruses that have been discovered till now are Severe Acute Respiratory Syndrome (SARS), Middle East Respiratory Syndrome (MERS), and Coronavirus Disease (COVID-19). COVID-19 is a pathogenic transmission of severe acute respiratory syndrome coronavirus 2 (SARS-CoV-2). ${ }^{2}$ Most people infected with COVID-19 in the initial phase of infection experience a moderate respiratory illness and recover without requiring any special treatment. ${ }^{1}$

After conducting various exploratory designs of research technique, it was deduced that the outbreak initiated from the Huanan seafood market of Wuhan city of China and rapidly infected more than 50 persons. The animals frequently sold at the seafood market are bats, snakes, birds, marmots, rabbits, and frogs. There has been evidence suggesting that persons who visited the seafood market got infected with SARS-CoV-2, although there are reports that suggest people who didn't visit the market also got infected. These observations indicated person to person spreading of COVID-19. ${ }^{4,5}$ The person to person spreading of COVID-19 occurs due to close contact with an infected person exposed to sneezing, coughing, respiratory droplets or aerosol. ${ }^{2}$

\section{Brief Timeline of COVID-19 Impacting the Globe}

On December 31, 2019, the WHO office in China recognised a cluster of cases of viral pneumonia of unknown cause. Further to this, on January 9, 2020, WHO declared that as per Chinese authorities, the cause behind the viral outbreak of pneumonia is novel coronavirus. ${ }^{6}$ On January 11,2020 , China announced its first death of a 61 -year-old woman due to COVID-19, who bought from the seafood market of Wuhan city of China. ${ }^{7}$ After doing various clinical investigations and upholding meetings with relevant professionals, on January 30, 2020, WHO declared novel coronavirus outbreak as a global emergency or a Public Health Emergency of International Concern (PHEIC). By the time WHO declared COVID-19 a PHEIC, there were 98 cases of COVID across the globe in 18 countries with no deaths outside China. On this very day of January 30,2020 , India was diagnosed with the first COVID-19 positive case in the state of Kerala - the infected person is a student of Wuhan University in China. ${ }^{8}$ On February 11, 2020, WHO announced that newly spread coronavirus must be called COVID-19 (Coronavirus Disease) and this new coronavirus was dubbed SARS-CoV-2. India's first death due to COVID-19 occurred on March 12, 2020, in the state of Karnataka, and to this day, the country was recorded with 78 total COVID positive cases. ${ }^{9}$ On June 11 , 2020, India surpassed UK to become the fourth largest COVID hit country in the world with 297,535 cases. ${ }^{10}$ India took 111 days since its first COVID positive case to cross the limit of one lakh COVID positive cases, which happened on May 19, 2020, and further, it took another 48 days to reach the limit of 7 lakh people in the country. On July 6 , 2020 , India overtook Russia to become the country with the third-highest number of cases to be affected by novel coronavirus cases (7.19 lakh COVID positive cases). ${ }^{11}$ On September 5, 2020, India overtook Brazil to become the second-ranked country in the perspective of COVID cases with the number of cases crossing the limit of 42 lakhs. ${ }^{12}$

\section{Material and Methods}

In wake of rising positive cases of COVID-19, the Prime Minister of India, on behalf of the Indian government, gave a call for a 14-hour voluntary public curfew on March 22, 2020. The government further extended it in the form of a complete lockdown in India from March 25, 2020 to April 14, 2020, and it was termed Lockdown 1.0. Similar to Lockdown 1.0, two other lockdowns (Lockdown 2.0 and Lockdown 3.0) were imposed in immediate succession to Lockdown 1.0. During the lockdown phase, all the public movement and vehicular traffic were dropped to zero except the mechanism related to the supply of essential and medical goods for containment of COVID-19 along with needed house based groceries. During the lockdown phase since the imposition of public curfew, it was ensured that public of the non-hotspot area (areas not diagnosed with COVID-19 positive cases in 21 days) should move out only for emergency provisions or as per the provisions allowed in lockdown guidelines issued by the Ministry of Home Affairs, Government of India. It was ensured by the concerned district administration of India that every individual staying within his/ her house receives all the essential supplies needed for ensuring his/ her well-being. The dates of various phases of lockdown and unlock can be viewed from Table 2 .

\section{Results}

A gradual downfall in the COVID-19 mortality rate can be seen around the completion of lockdown (May 31, 2020) and the same has been depicted in Figure 3, which has been plotted regarding the beginning and completion dates of lockdowns and unlock in India. The data plotting has been done in the perspective of Table 2, signifying the COVID cases in the country in correspondence to respective dates of lockdown and unlock in India.

\section{India: Nation with the Least Mortality in Countries with Population $>\mathbf{2 0 0}$ crore}

The unprepared closeness between individuals is a major cause for the spreading of the pandemic. So, population 
density has been considered as the major cause in this article as the same may increase the spread of COVID-19 in densely populated developing countries having a high influx of tourists or people returning from other nations. Also, we know higher is the population density, higher will be the chance of ignorance of social distancing between persons. It can be deduced clearly from Table 1 and Figure 1 that India has the highest population density (420 persons per square kilometre) in countries with a population of more than 200 million, that has been recorded with the lowest COVID mortality rate (1.65\%) till September 13, 2020, and the absolute figures of the same can be seen from Table 2 .

\section{India: Declining Pandemic Mortality with the Lockdown}

It can be seen from Figure 2 that the number of COVID positive cases in India have substantially increased with the removal of Lockdown 3.0. The downfall in COVID mortality rate with an increase in COVID positive cases is expected to be recorded due to the meticulous implementation of capacity building programmes by various ministries of India for boosting the immunity through the platform of the press and electronic media, audio-video messages at crowded places, etc. and by utilising the capacities of frontline workers. This is considered to be a significant cause for the reduction in COVID mortality rate. The lockdown in India was consecutively followed by unlocking of India by removing restrictions in a phase-wise manner similar to that of Lockdown 1.0, 2.0, and 3.0 as shown in Table 2. The unlocking was done in a phased manner to avoid the chances of crowd mismanagement leading to negligence of social distancing between individuals, which may increase COVID cases in the country by multiple folds.

Table I.COVID-I9C in 8 Most Populated Countries of the World till September I3, 2020I3, I4

\begin{tabular}{|c|c|c|c|c|c|}
\hline Countries & Population & $\begin{array}{c}\text { Population Density } \\
\text { (Number of persons/km2) }\end{array}$ & $\begin{array}{c}\text { COVID-19 } \\
\text { Positive Cases }\end{array}$ & $\begin{array}{c}\text { Deaths due } \\
\text { to COVID-19 }\end{array}$ & $\begin{array}{c}\text { Mortality Rate } \\
\text { (\%) }\end{array}$ \\
\hline China & $1,394,015,977$ & 148 & 91121 & 4746 & 5.208459082 \\
\hline India & $1,326,093,247$ & 420 & 6549373 & 101782 & 1.554072428 \\
\hline USA & $332,639,102$ & 35 & 7256234 & 207366 & 2.857763407 \\
\hline Indonesia & $267,026,366$ & 144 & 299506 & 11055 & 3.691077975 \\
\hline Pakistan & $233,500,636$ & 250 & 314616 & 6513 & 2.07014265 \\
\hline Nigeria & $214,028,302$ & 223 & 59287 & 1113 & 1.877308685 \\
\hline Brazil & $211,715,973$ & 25 & 4880523 & 145388 & 2.978943035 \\
\hline
\end{tabular}

Table 2.Lockdown Analytics in the perspective of India 14

\begin{tabular}{|c|c|c|c|c|}
\hline Significance of Date & Date & $\begin{array}{c}\text { COVID-19 } \\
\text { Positive Cases }\end{array}$ & $\begin{array}{c}\text { Deaths due to } \\
\text { COVID-19 }\end{array}$ & $\begin{array}{c}\text { COVID-19 Mortality } \\
\text { Rate }\end{array}$ \\
\hline First day of Lockdown 1.0 & 25-Mar-20 & 562 & 9 & 1.601423 \\
\hline Completion of Lockdown 1.0 (21 Days) & 14-Apr-20 & 10363 & 339 & 3.271253 \\
\hline Beginning of Lockdown 2.0 & 15-Apr-20 & 11439 & 377 & 3.295743 \\
\hline Completion of Lockdown 2.0 (19 Days) & 3-May-20 & 39980 & 1301 & 3.254127 \\
\hline Beginning of Lockdown 3.0 & 4-May-20 & 42533 & 1373 & 3.228082 \\
\hline Completion of Lockdown 3.0 (14 Days) & 17-May-20 & 90927 & 2872 & 3.158578 \\
\hline Beginning of Lockdown 4.0 & 18-May-20 & 96169 & 3029 & 3.149664 \\
\hline Completion of Lockdown 4.0 (14 Days) & 31-May-20 & 182143 & 5164 & 2.835135 \\
\hline Begining of Unlock 1.0 & 1-Jun-20 & 190535 & 5394 & 2.830976 \\
\hline Completion of Unlock 1.0 (30 Days) & 30-Jun-20 & 566840 & 16893 & 2.980206 \\
\hline Begining of Unlock 2.0 & 1-Jul-20 & 585493 & 17400 & 2.971854 \\
\hline Completion of Unlock 2.0 (31 Days) & 31-Jul-20 & 1638870 & 35747 & 2.181198 \\
\hline Beginning of Unlock 3.0 & 1-Aug-20 & 1695988 & 36511 & 2.152786 \\
\hline Completion of Unlock 3.0 (31 Days) & 31-Aug-20 & 3679782 & 65355 & 1.776056 \\
\hline Beginning of Unlock 4.0 & 1-Sep-20 & 3758764 & 66376 & 1.7659 \\
\hline Completion of Unlock 4.0 & 30-Sep-20 & 6301156 & 98585 & 1.564554 \\
\hline
\end{tabular}




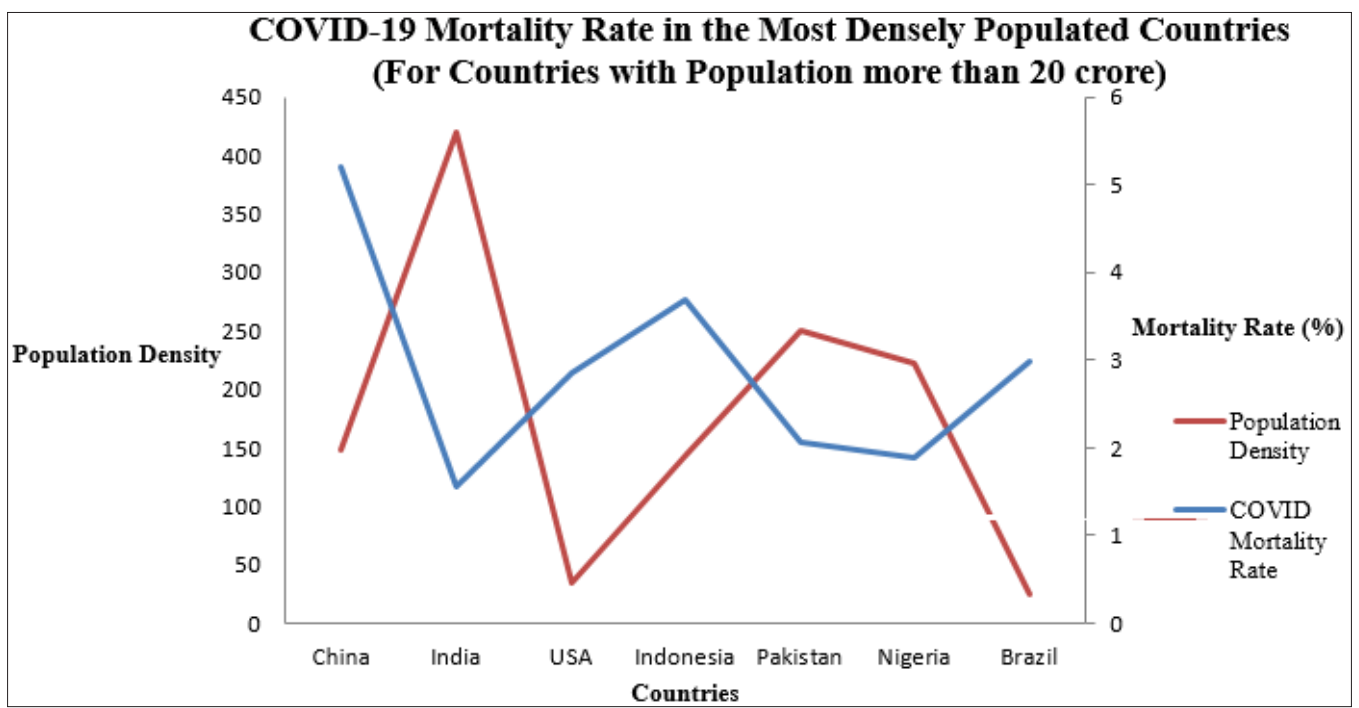

Figure I.COVID- 19 cases in the 8 Most Populated Countries of the World till September I3, 2020

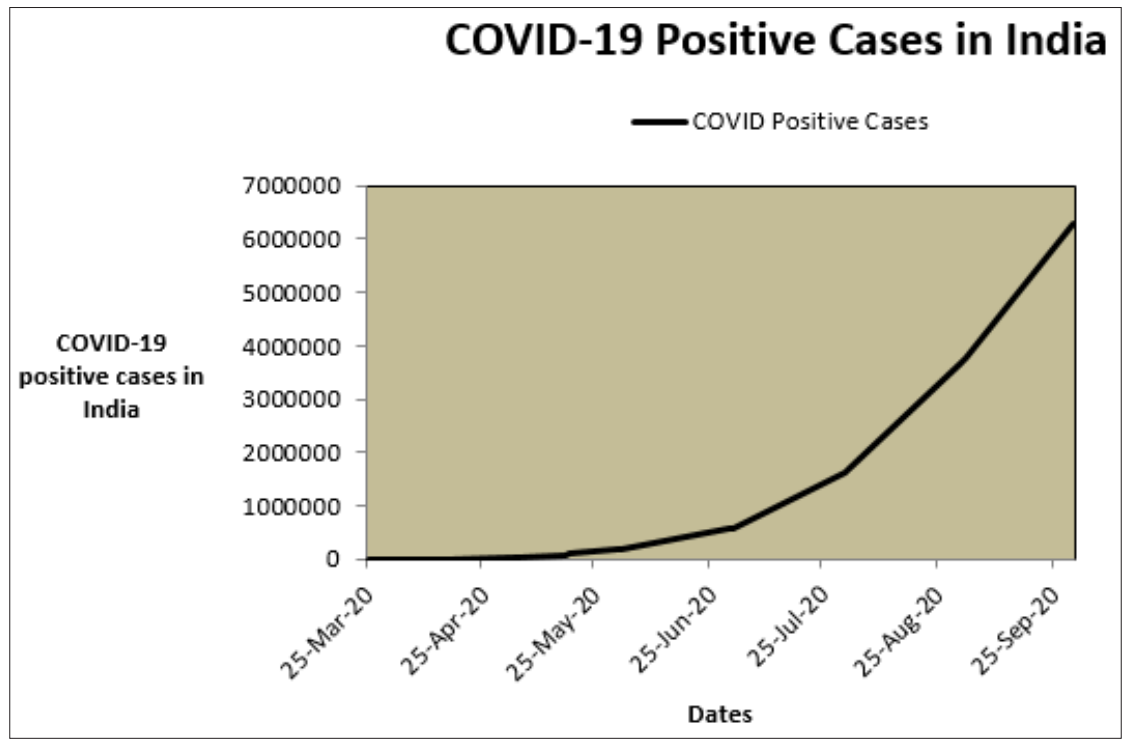

Figure 2.COVID-19 Cases in India with respect to Phases of Lockdown and Unlock

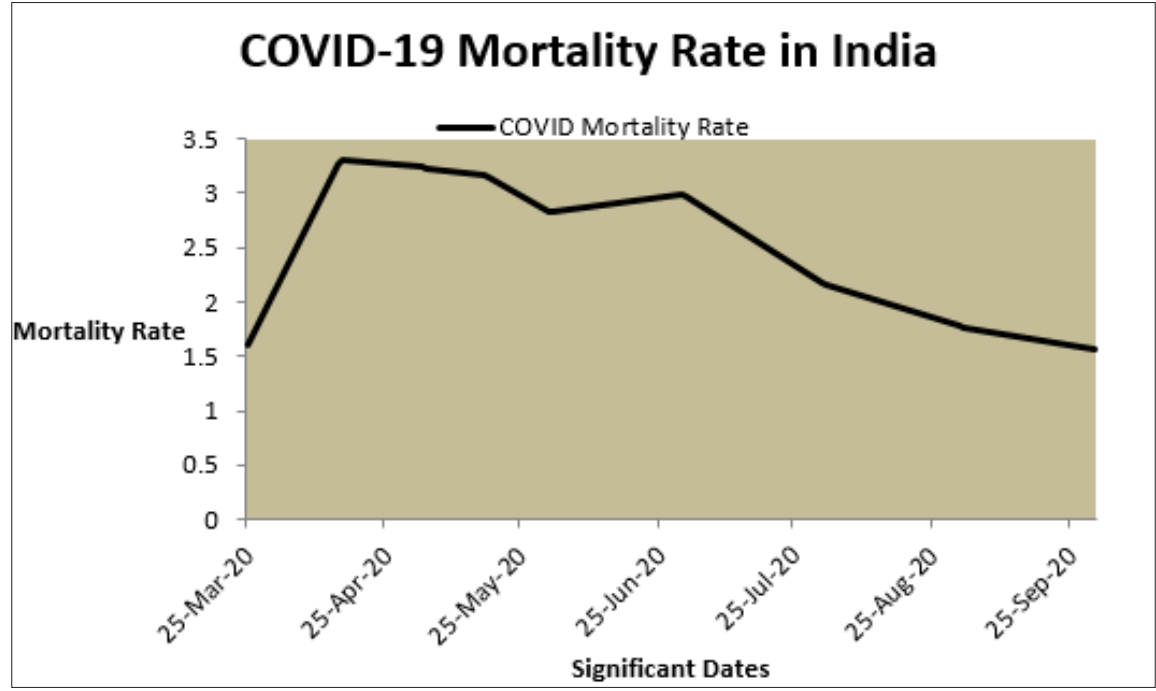

Figure 3.COVID-19 Mortality Rate in India with respect to Phases of Lockdown and Unlock 


\section{Impact of Lockdown on Migrants and Employment in India}

The imposition of nationwide lockdown to contain the spread of COVID-19 has led to a substantial economical shortfall by affecting the entire race of humans and related organisations across the globe. A significant amount of Indian workers - majorly belonging to the unorganised sector faced either a layoff or salary cuts due to the loss caused to their organisation in lockdown. As per the 201718 surveyed data, India has an overall strength of 465 million workers, out of which $91 \%$ (422 million) of workers belong to the unorganised sector. ${ }^{15}$ As per a joint report of the International Labour Organization (ILO) and Asian Development Bank (ADB), 41 lack youths and the majority of workers belonging to the sector of construction and farming lost their job in the current phase of COVID-19. ${ }^{16}$ Also, as per the Centre for Monitoring Indian Economy (CMIE), more than 12.2 crore Indians belonging to the class of traders and wage labourers lost their job in April, 2020 due to the lockdown ${ }^{17}$; Federation of Indian Tourism and Hospitality (FAITH) and Confederation of Indian Industry (CII) claimed that sectors comprising tour operators, transport providers, hotels and restaurants, airlines, and other allied businesses are going to face a loss of 38 million to 50 million workers directly or indirectly due to lockdown ${ }^{18}$; Clothing Manufacturers Association of India (CMAI) claimed that the textile sector might suffer a loss of 1 crore jobs due to lockdown.

Due to job cuts experienced by the workers of the unorganised sector, they faced a lot of difficulty in running their livelihood. Moreover, when the migrants started returning, they faced issues like scarcity of transport, food, water and lodging which combined with walking for hundreds of kilometres on the highways exhausted them and made them weak. When they reached their native town after spending time at the nearest quarantine centre, they faced issues like discrimination by the local communities as the locals debarred them socially thinking that migrants are infected with COVID-19 and can infect anybody else whoever comes in contact with them.

\section{Impact of COVID-I9 on Women and Children - Focusing on India}

In a country like India, where more than $92 \%$ of women spend most of their daily time on domestic work, ${ }^{19}$ this economical crisis has created a difficult scenario for the housewives to look after the well being of their respective family members. The above issue has dragged women into a state of anxiety and annoyance. In some cases, domestic violence on women has risen in India further to the imposition of lockdown ${ }^{20}$ and in some cases, men and children have been observed helping more with the household work than before lockdown, which has alleviated some pressure on the woman. ${ }^{21}$ Soon after the outbreak of the pandemic, it was revealed that the mortality rate due to Severe Acute Respiratory Syndrome Coronavirus 2 (SARS-CoV-2) is higher in men than in women.

The lockdown led to the closure of schools, parks, cinema halls, community centres, playgrounds, etc. which developed anxiety, despair, annoyance, and loneliness among the children. This global economic crisis is expected to put economical stress on families due to which children, particularly girls are at the risk of exploitation, child labour, and gender-based violence.

\section{Conclusion}

The analysis done in this article reveals that India has considerably reduced its COVID-19 mortality rate. The pandemic mortality rate was rising before the imposition of lockdown, during the lockdown-it was nearly stable, and after the completion of lockdown-it started declining. The steps adopted by the government of India for curbing the spread of COVID-19 is the research on discovering the vaccine for COVID-19, expansion of the hospital infrastructure-such as practical implications of medicines to provide symptomatic treatment leading to curing of COVID-19 affected persons and capacity building done by various ministries for following do's and don'ts for COVID-19. The pandemic-COVID-19 has hampered the livelihood of vulnerable communities like migrant workers, women, and children and in lieu of the same, governments across the globe needs to adopt preventive measures by launching government schemes and programs for ensuring the well being of the people affected by COVID-19. For example- government schemes can be launched to offer significant tax exemption to enterprises (one's affected by COVID-19) in response to which enterprises will be required to do zero salary cuts and zero layoff of the employees. Similar steps can be researched and planned In the context of India to counter any forthcoming risk of the pandemic at a larger scale.

\section{Source of Funding: None Conflict of Interest: None \\ References}

1. MoHFW [Internet]. Role of Frontline Workers in Prevention and Management of Corona Virus. 2020. Available from: https://www.mohfw.gov.in/pdf/ PreventionandManagementofCOVID19FLWEnglish.pdf

2. Shereen MA, Khan S, Kazmi A, Bashir N, Siddique R. COVID-19 infection: Origin, transmission, and characteristics of human coronaviruses. J Adv Res. 2020;24:91-8. [PubMed] [Google Scholar]

3. Kahn JS, Mclntosh K. History and recent advances in coronavirus discovery. Pediatr Infect Dis J. 2005;24:S2237. [PubMed] [Google Scholar] 
4. Parry J. China coronavirus: cases surge as official admits human to human transmission. BMJ. 2020;368:m236. [PubMed] [Google Scholar]

5. Wang C, Horby PW, Hayden FG, Gao GF. A novel coronavirus outbreak of global health concern. Lancet. 2020;395(10223):470-3. [PubMed] [Google Scholar]

6. WHO [Internet]. Listings of WHO's response to COVID-19. 2020. Available from: https://www.who. int/news-room/detail/29-06-2020-covidtimeline

7. Alzazeera [Internet]. Timeline: How the new coronavirus spread. 2020. Available from: https://www.aljazeera. com/news/2020/01/timeline-china-coronavirusspread-200126061554884.html

8. Reid D. India confirms its first coronavirus case. CNBC [Internet]. 2020. Available from: https://www.cnbc. com/2020/01/30/india-confirms-first-case-of-thecoronavirus.html

9. The Hindu [Internet]. India's first COVID-19 death confirmed in Karnataka; total number of cases touch 78. 2020. Available from: https://www.thehindu.com/ sci-tech/health/indias-first-covid-19-death-confirmedin-karnataka-total-number-of-cases-cross-70/ article31053153.ece

10. Chaudhary A. India becomes fourth worst-hit country after coronavirus cases exceed UK. The Print [Internet]. 2020. Available from: https://theprint.in/india/indiabecomes-fourth-worst-hit-country-after-coronaviruscases-exceed-uk/440343/\#: :text=New Delhi\%3A

11. Jagran [Internet]. How India became 3rd worst-hit nation from COVID-19 after recording 6 lakh cases in just 48 days | A complete timeline. 2020. Available from: https://english.jagran.com/india/how-indiabecame-3rd-worsthit-nation-from-covid19-afterrecording-6-lakh-cases-in-just-48-days-a-completetimeline-10013675

12. Sinha A. India overtakes Brazil, now No. 2 in global Covid cases. Indian Express [Internet]. 2020. Available from: https://indianexpress.com/article/india/ india-overtakes-brazil-now-no-2-in-global-covidcases-6585882/

13. United Stated Census Bureau [Internet]. US Census bureau current population. 2020. Available from: https://www.census.gov/popclock/print. php?component=counter

14. WHO [Internet]. Coronavirus disease 2019 (COVID-19) Weekly Epidemiological Update and Weekly Operational Update. 2020. Available from: https://www.who. int/emergencies/diseases/novel-coronavirus-2019/ situation-reports

15. Dev SM. Addressing COVID-19 impacts on agriculture, food security, and livelihoods in India. International Food Policy Research Institute [Internet]. 2020. Available from: https://www.ifpri.org/blog/addressing-covid-19- impacts-agriculture-food-security-and-livelihoods-india [Google Scholar]

16. The Economic Times [Internet]. 41 lakh youths lose jobs in India due to COVID-19 pandemic: ILO-ADB Report. 2020. Available from: https://economictimes. indiatimes.com/news/economy/indicators/41-lakhyouth-lose-jobs-in-india-due-to-covid-19-pandemicilo-adb-report/articleshow/77613218.cms

17. The Hindu Data Team. Data | An estimated 12.2 crore Indians lost their jobs during the coronavirus lockdown in April: CMIE. The Hindu [Internet]. 2020. Available from: https://www.thehindu.com/data/data-over-12crore-indians-lost-their-jobs-during-the-coronaviruslockdown-in-april/article31520715.ece

18. Chaturvedi A. Tourism and hospitality industry begins layoff. Economic Times [Internet]. 2020. Available from: https://economictimes.indiatimes. com/jobs/tourism-hospitality-industry-begins-layoffs/ articleshow/75854257.cms

19. Singh M. $64 \%$ of urban Indian women busy with housework, study reveals. Times of India [Internet]. 2020. Available from: http://timesofindia. indiatimes.com/articleshow/44796358.cms?utm_ source=contentofinterest\&utm_medium=text\&utm_ campaign $=$ cppst

20. Times of India [Internet]. Domestic violence cases in India on the rise during lockdown, says report. 2020. Available from: https://timesofindia.indiatimes.com/ life-style/relationships/love-sex/domestic-violencecases-in-india-on-the-rise-during-lockdown-saysreport/articleshow/75801752.cms

21. Jha R. Impact of COVID-19 on Women and Children in South Asia. Inter Press Service (News Agency) [Internet]. 2020. Available from: http://www.ipsnews. net/2020/07/impact-covid-19-women-children-southasia/ 